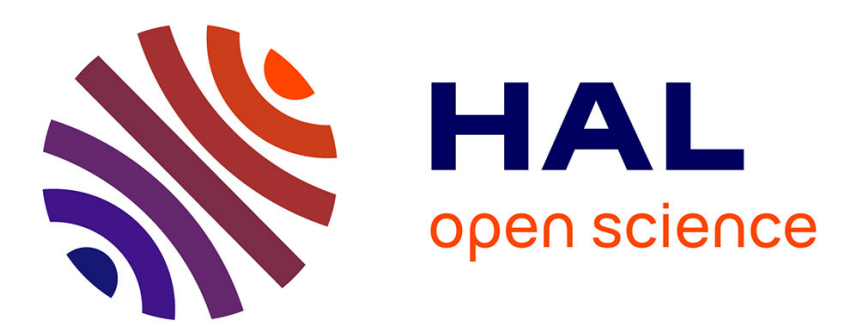

\title{
10 years of nonlinear optics in photonic crystal fiber: progress and perspectives
}

\author{
J.M. Dudley
}

\section{To cite this version:}

J.M. Dudley. 10 years of nonlinear optics in photonic crystal fiber: progress and perspectives. IEEE/LEOS Winter Topicals Meeting, Jan 2009, Innsbruck, Austria. pp.180, 10.1109/LEOSWT.2009.4771717 . hal-00472296

\section{HAL Id: hal-00472296 \\ https://hal.science/hal-00472296}

Submitted on 29 Apr 2021

HAL is a multi-disciplinary open access archive for the deposit and dissemination of scientific research documents, whether they are published or not. The documents may come from teaching and research institutions in France or abroad, or from public or private research centers.
L'archive ouverte pluridisciplinaire HAL, est destinée au dépôt et à la diffusion de documents scientifiques de niveau recherche, publiés ou non, émanant des établissements d'enseignement et de recherche français ou étrangers, des laboratoires publics ou privés. 


\title{
10 years of nonlinear optics in photonic crystal fiber: progress and perspectives
}

\author{
John. M. Dudley \\ Department of Optics, Institut FEMTO-ST, UMR 6174 CNRS-Université de Franche-Comté, Besançon, France \\ john.dudley@univ-fcomte.fr
}

\begin{abstract}
- 2009 marks ten years since the first report of supercontinuum generation in photonic crystal fiber. These results have had wide-reaching impact, and continue to stimulate new research directions in nonlinear dynamics and nonlinear optics.
\end{abstract}

\section{Index Terms - Nonlinear optics, ultrafast processes in fibers.}

The development of photonic crystal fibres (PCF) in the 1990 's has opened up a number of new frontiers in guided wave optics [1]. The potential of PCF in the field of nonlinear fiber optics was illustrated in striking fashion during the postdeadline session of the Conference on Lasers and ElectroOptics (CLEO) in Baltimore in May 1999. Specifically, Ranka et al. from Bell Laboratories used 100 fs nanojoule energy pulses from a self modelocked Ti:Sapphire laser to generate a supercontinuum from 400-1500 nm using a PCF fabricated such that its zero dispersion wavelength was close to the laser pump wavelength of $800 \mathrm{~nm}$ [2]. In fact, shortly afterwards in the same year, Broderick et al. discussed nonlinearity engineering in PCF and reported careful experimental measurements of the enhanced nonlinear phase shifts that could be obtained [3].

These results clearly showed the key advantages of PCF for applications in nonlinear frequency conversion, and this has been confirmed unequivocally by a decade of subsequent research. Supercontinuum generation itself has of course had revolutionary impact on the field of precision frequency metrology, and its role in the award of the 2005 Nobel Prize has been well-documented [4].

However, although the fundamental mechanisms of supercontinuum generation are now well-understood [5], new aspects of nonlinear propagation effects in PCF continue to be uncovered, and new applications continue to be developed. From a fundamental viewpoint, although numerical modelling has been very successful in designing and modelling supercontinuum experiments, recent work has provided muchimproved physical insights through (sometimes unexpected) links with other areas of physics. For example, although cross phase modulation and the Raman self-frequency shift are well-known effects in fiber optics, their combined influence has been interpreted in terms of a gravitational-like potential that traps radiation on the supercontinuum short wavelength edge. This insight has subsequently allowed an analytic approach to be used to calculate the short wavelength spectral structure, complementing existing numerical approaches [6].
Other work has also made links with gravitational effects to speculate that certain features of supercontinuum spectra can be interpreted in terms of an event-horizon [7]. Further studies of a fundamental nature have revisited the supercontinuum stability properties, showing that supercontinuum spectral broadening can lead to the generation of optical rogue waves - large amplitude instabilities analogous to the infamous and destructive freak waves observed on the surface of the ocean [8]. These results now seem to be opening up a new field studying similar "extreme value" events in other areas of nonlinear optics.

At the same time as these fundamentally-oriented studies, work on applications of nonlinear spectral broadening in PCF has also advanced rapidly [9]. There has been continued progress in the field of optical frequency metrology using femtosecond pumped supercontinuum generation, but a wide selection of other new results have also been reported: research into spectral generation using more compact sources and at higher average powers; "non-supercontinuum" applications related to parametric frequency conversion; pulse compression; and even nonlinear propagation effects in nonPCF waveguides with similarly engineered dispersion and nonlinearity. A particular aim of this talk will be to highlight the new and emerging areas of research which continue to take this field in new and exciting directions.

\section{REFERENCES}

[1] P. St J. Russell, "Photonic-Crystal Fibers," J. Lightwave Technol. 24, 4729-4749 (2006)

[2] J. K. Ranka, R. S. Windeler, and A. J. Stentz, in Conference on Lasers and Electro-Optics, 1999 OSA Technical Digest Series (Optical Society of America, Washington, D.C., 1999), postdeadline paper CPD8 (1999)

[3] N. G. R. Broderick, T. M. Monro, P. J. Bennett, and D. J. Richardson, "Nonlinearity in holey optical fibers: measurement and future opportunities," Opt. Lett. 24, 1395-1397 (1999)

[4] J. L. Hall, "Nobel Lecture: Defining and measuring optical frequencies," Rev. Mod. Phys. 78, 1279 (2006); T. W. Haensch, "Nobel Lecture: Passion for precision," Rev. Mod. Phys. 78, 1297 (2006)

[5] J. M. Dudley, G. Genty, S. Coen, "Supercontinuum Generation in Photonic Crystal Fiber," Rev. Mod. Phys., 78 1135-1184 (2006)

[6] A. Gorbach and D.V. Skryabin, "Light trapping in gravity-like potentials and expansion of supercontinuum spectra in photonic crystal fibers," Nature Photonics 1, 653 - 657 (2007)

[7] T.G. Philbin, C. Kuklewicz, S. Robertson, S. Hill, F. Konig, and U. Leonhardt, "Fiber-Optical Analog of the Event Horizon," Science 319, 1367-1370 (2008)

[8] D. R. Solli, C. Ropers, P. Koonath, and B. Jalali, "Optical rogue waves," Nature, 450, p. 1054 (2007)

[9] See for example: Shum, P., Knight, J. C., Love, J., Yan M. (Eds) Symposium on Microstructured and Nanostructured Optical Fibers in ICMAT 2007, Optical and Quantum Electronics 39, 947-1143 (2007) 